\title{
Diagenesis of Upper Jurassic sandstones of the Blokelv-1 core in the Jameson Land Basin, East Greenland
}

\author{
Mette Olivarius, Rikke Weibel, Niels H. Schovsbo, Dan Olsen and Claus Kjøller
}

\begin{abstract}
Petrographic analysis combined with X-ray diffraction are used to identify the diagenetic changes that have affected the porosity and permeability of gravity-flow sandstones of the Oxfordian-Volgian Hareelv Formation in the cored Blokelv-1 borehole in Jameson Land. Kaolinite replacement of albite grains probably occurred early after deposition and microquartz coatings formed under shallow burial. At deeper burial, illite and quartz formed from kaolinite and K-feldspar. Pervasive ankerite cement formed in the finest grained sandstones and may have formed at the expense of early calcite cement. Quartz overgrowths are volumetrically small, partly due to inhibition by microquartz coatings and partly due to limited residence time during deep burial. The succession reached the maximum burial depth of $c .2 .8 \mathrm{~km}$ during the late Eocene. Basaltic material was intruded into the sediments during the early Eocene and the enhanced heat flow accelerated diagenesis in the close vicinity of the intrusions, which have thicknesses of up to $2 \mathrm{~m}$. Most of the sandstones have porosities between 14.4 and $25.7 \%$ and permeabilities between 0.4 and $411.9 \mathrm{mD}$; this variation resulted from a combination of microquartz coatings and clay minerals. However, the intrusion-influenced sandstones and the ankerite-cemented sandstones have lower porosity and permeability.
\end{abstract}

Keywords: East Greenland, Hareelv Formation, Katedralen and Sjællandselv Members, Oxfordian-Kimmeridgian, petrography, mineralogy, reservoir quality.

Geological Survey of Denmark and Greenland, Øster Voldgade 10, DK-1350 Copenhagen K, Denmark.

E-mail:mol@geus.dk

The Blokelv-1 fully cored borehole was drilled with almost full recovery to a total depth of $234 \mathrm{~m}$ in southern Jameson Land, East Greenland within the central part of the Jameson Land Basin (Fig. 1; Bjerager et al. 2018a, this volume). Laminated mudstones dominate the cored succession of Jurassic sediments referred to the Hareelv Formation. Sandstone layers make up 36\% of the core and are generally 1-7 $\mathrm{m}$ thick, and heterolithic bedded intervals make up $11 \%$ of the cored succession (Fig. 2; Bjerager et al. 2018a, this volume). Good reservoir quality is present in most of the sandstones, and the interbedded mudstones constitute rich gas/oil-prone source rocks (Bojesen-Koefoed et al. 2018, this volume). Thus, the Blokelv-1 succession may act as an analogue for similar sandstonemudstone complexes in the North Atlantic region.
The purposes of this study are: (1) to determine the diagenetic development of the sandstones of the Hareelv Formation in order to explain their large variation in porosity and permeability; (2) to relate the observed mineralogical changes to diagenetic processes caused by burial and igneous intrusion; and (3) to interpret their effect on porosity evolution in the sandstones.

\section{Geological setting}

Thick post-Caledonian sedimentary successions were deposited in East Greenland in response to basin development during thermal subsidence and rifting (Stemmerik et al. 1992; Surlyk 2003). The Devonian-Jurassic 


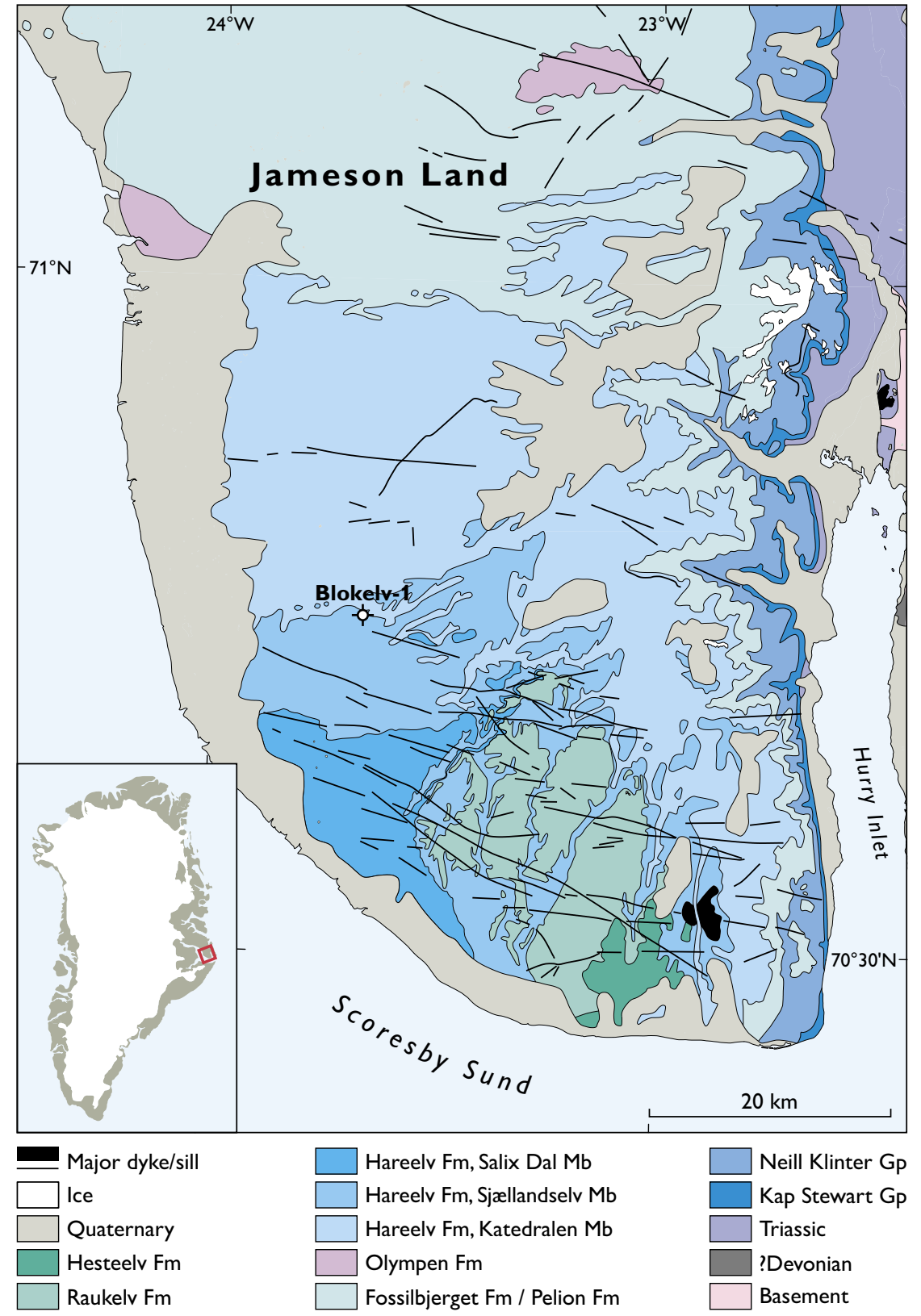

Fig. 1. Geological map of Jameson Land in East Greenland showing the location of the fully-cored Blokelv-1 borehole. The Triassic-Cretaceous sediments are intersected by numerous igneous intrusions. Based on the digital Greenland geological map at a scale of 1:500 000 (data.geus.dk) map2/geogreen) and the printed map series at a scale of 1:100 000. succession in the Jameson Land Basin has a thickness of up to about $18 \mathrm{~km}$ (Larsen \& Marcussen 1992), of which the Jurassic sediments comprise $2 \mathrm{~km}$ (Bjerager $e t$ al. 2018a, this volume). Younger sediments were largely eroded during Cenozoic uplift of the Jameson Land area (Mathiesen et al. 2000; Hansen et al. 2001), although the Cretaceous Hesteelv Formation is preserved as a thin cover in southernmost Jameson Land (Fig. 1). The exhumation of the studied succession began in the late Eocene and renewed uplift took place from the late Miocene and onwards (Green \& Japsen 2018, this volume); these are widely known events along the East Greenland margin (Japsen et al. 2014).
Organic-rich mudstones were deposited in central areas of the Jameson Land Basin during the Late Jurassic; anoxic conditions prevailed in relatively deep water, well below storm wave base. Such mudstones comprise the majority of the Hareelv Formation in the Blokelv-1 core (Fig. 2; Surlyk et al. 2007; Bjerager et al. 2018a, this volume). The interbedded sandstones were deposited from gravity flows in lower slope and basin-floor settings (Fig. 3 ). Most of the sandstone beds in the Blokelv-1 core belong to the Oxfordian-Kimmeridgian Katedralen Member of the Hareelv Formation; some of these gravity-flow sands were remobilised and injected into the surrounding mudstones. The coarsest and thickest gravity-flow sand- 
stone bed in the Blokelv-1 core is present in the uppermost part where it is referred to the Volgian Sjællandselv Member of the Hareelv Formation (Fig. 2).

The sediment in the gravity-flow sandstones of the Katedralen Member is interpreted to have been fed by collapse of drowned shelf-edge deposits exemplified by the Zeus Member of the Oxfordian Olympen Formation situated at the northern margin of the basin (Fig. 3A; Surlyk et al. 2007; Bjerager et al. 2018b, this volume). The latter sand unit represents a southwards-prograding delta that accumulated under lowstand conditions prior to deposition of the Katedralen Member (Larsen \& Surlyk 2003). The Katedralen Member accumulated during a major transgressive pulse that culminated in the Late Kimmeridgian. The subsequent relative sea-level fall in the Early Volgian was heralded by the influx of gravityflow sands forming the Sjællandselv Member, derived from shelf-edge sands analogous to the younger Raukelv Formation (Fig. 3B) that prograded east and southwards into the basin (Surlyk 2003; Bjerager et al. 2018b, this volume).

The provenance of the Hareelv Formation comprises Archaean-Palaeoproterozoic crystalline complexes, Meso-Neoproterozoic metamorphic rocks and Caledonian migmatites and granites; some or all of the material may have been through several cycles of sedimentation prior to deposition in the Late Jurassic in the Jameson Land Basin (Olivarius et al. 2018, this volume).

\section{Samples and methods}

The sampled sandstones are grey, moderately to wellsorted and very fine- to medium-grained (Fig. 4; Bjerager et al. 2018a, this volume). Analyses of both bulk and clay mineralogy were carried out by X-ray diffraction (XRD) on 22 samples comprising 18 sandstones, one mudstonedominated heterolith and three mudstones. The sandstone intervals were sampled to reflect the full spectrum of facies present in the succession; sandstone samples were also taken close to the contacts with mudstones and igneous intrusions to investigate if the proximity to these had an effect on the diagenesis. Thin sections were made of 25 sandstone samples that were selected on the basis of both representivity and diversity. Quantitative determination of detrital and authigenic mineral content was made by point counting of thin sections prepared from nine sandstone samples to constrain the mineralogy further, and the selected intervals correspond to nine of the XRD analyses. Scanning electron microscopy (SEM) analyses were carried out to determine the morphology of the minerals and the relative timing of the diagenetic processes.

Geochemical analyses of 42 samples are reported by Bjerager et al. (2018a, this volume) and the results are used here as input parameters in a principal component analysis (PCA) in order to determine the relationships between the geochemistry and the mineralogy. He-porosity, air permeability and grain density measurements are also reported by Bjerager et al. (2018a, this volume) and their results from 18 sandstone samples are included here and used in the interpretation of reservoir quality. Core scanning data (spectral gamma-ray, bulk density) are also described by Bjerager $e$ al. (2018a, this volume) along with the log-derived porosity and permeability logs; three selected intervals of these logs are presented here at high resolution to illustrate the relationships to the mineralogical data.

\section{X-ray diffraction}

Bulk mineralogy was measured by XRD on half-core samples of 3-4 cm length. The rim of the core was removed prior to crushing to $<63 \mu \mathrm{m}$. The Bragg-Brentano method was applied utilising a Bruker Advance D8 diffractometer with a Lynx-Eye detector. The bulk mineralogy was quantified by the Rietveld method (Rietveld 1969; McCusker et al. 1999).

The clay mineralogy was measured by XRD on halfcore samples of 5-6 cm length when sand was dominant and of 1-2 cm length when clay dominated. The samples were gently hand-ground to pass a $250-\mu \mathrm{m}$ sieve. Organic matter was removed in the chemical pre-treatment using $\mathrm{NaOCl}$ at $\mathrm{pH}$ 9.0. The samples were dispersed ultrasonically in distilled water to obtain the clay fraction $<2 \mu \mathrm{m}$ for analysis. The fraction $>30 \mu \mathrm{m}$ was removed by sedimentation and the 2-30 $\mu \mathrm{m}$ fraction was separated in a centrifugal particle-size analyser (Slater \& Cohen 1962). The resulting suspension was flocculated in $1 \mathrm{M} \mathrm{NaCl}$. Excess salt was removed by centrifugation and washing with water and ethanol. The clay fraction was then airdried. Three oriented specimens were prepared for each sample by the pipette method as follows: Mg-saturated air-dry, $\mathrm{Mg}$-saturated with glycerol added to the suspension and K-saturated air-dry heated for 1 hour at $300^{\circ} \mathrm{C}$. The XRD analysis was carried out on randomly oriented specimens using a Philips 1050 goniometer with fixed divergence, anti-scatter slits and $\mathrm{Co}-\mathrm{K} \alpha$ radiation (pulsehigh selection and Fe-filter). An X-ray diffractogram was produced for each of the three saturated specimens for each sample. The discrete minerals were identified 

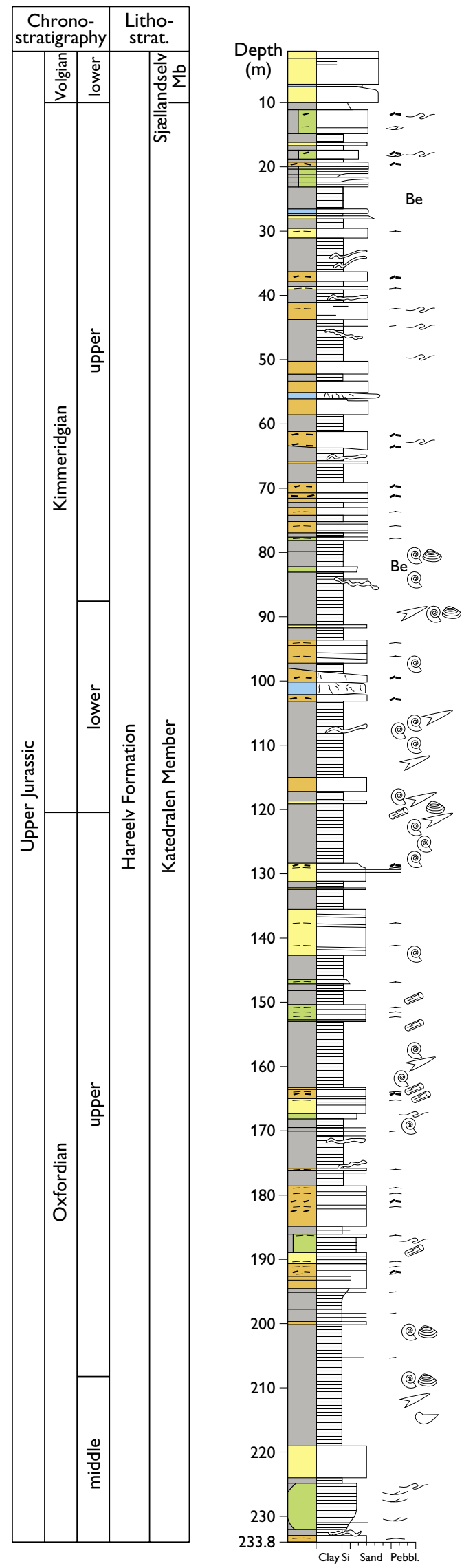

Lithology

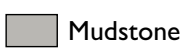

Heterolith

(mudstone/sandstone)

Sandstone

Sandstone, remobilised (intruded)

Igneous intrusion

Structures, biota

\begin{tabular}{|c|c|}
\hline & Parallel lamination/bedding \\
\hline- & Diffuse stratification \\
\hline & Ripple cross-lamination \\
\hline & Wavy bedding \\
\hline & Slump \\
\hline$\approx$ & Sandstone intrusion \\
\hline & Small mudstone intraclasts \\
\hline & Large mudstone clast \\
\hline $\mathrm{Be}$ & Bentonite \\
\hline 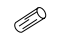 & Coalified wood \\
\hline$\vartheta$ & Belemnite \\
\hline () & Ammonite \\
\hline 의 & Bivalve \\
\hline & Brachiopod \\
\hline
\end{tabular}

Fig. 2. Sedimentological log of the Blokelv-1 core including chrono- and lithostratigraphy. The log is from Bjerager et al. (2018a, this volume) and the biostratigraphy is from Alsen \& Piasecki (2018, this volume). 

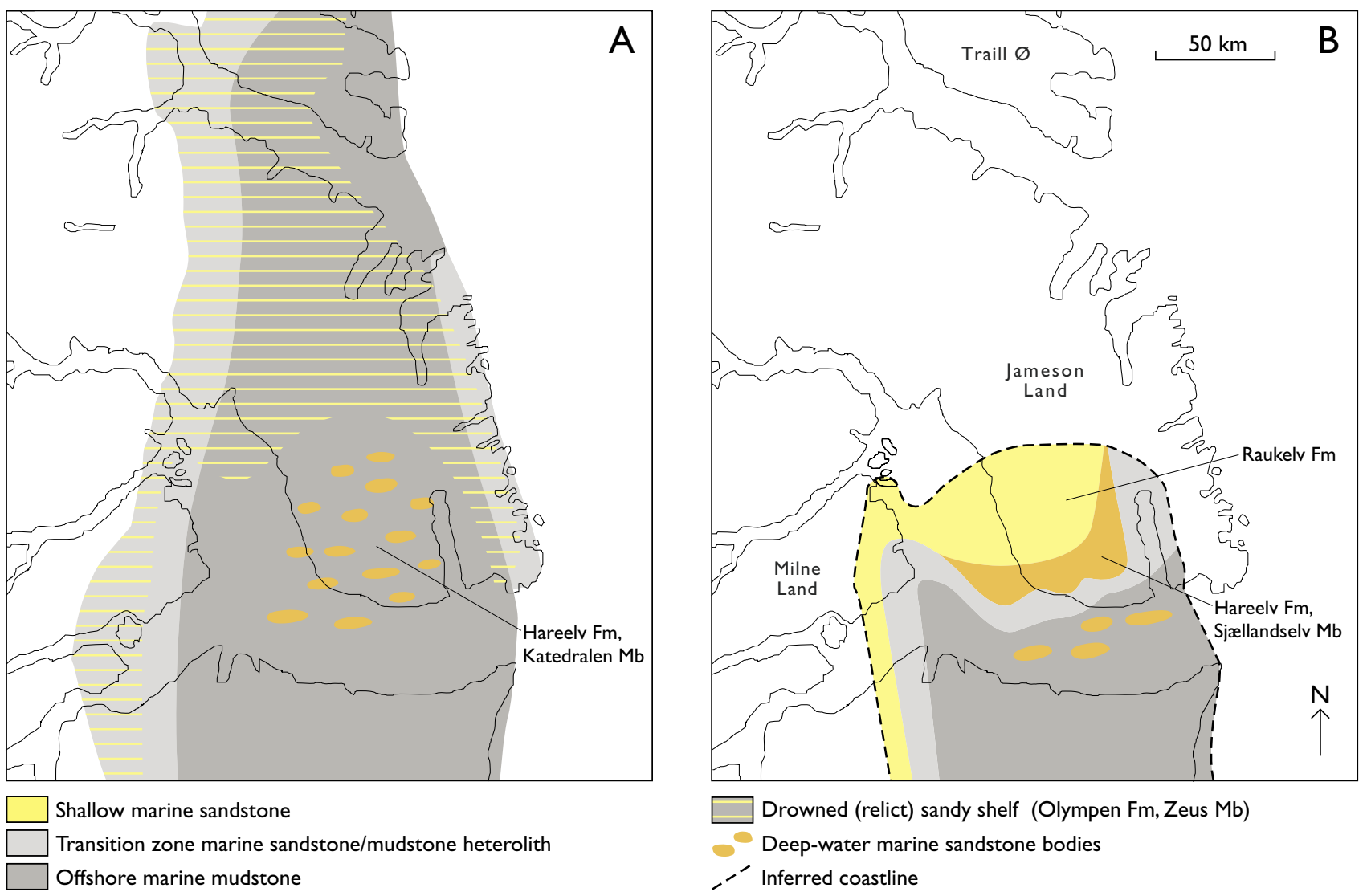

Fig. 3. Palaeogeographic reconstructions for the Katedralen Member (A) and Sjællandselv Member (B) of the Hareelv Formation (modified after Surlyk 2003; see Bjerager et al. 2018b, this volume). The facies distribution is tentative in most areas since the distribution in the presentday offshore area is inferred and the succession has been removed by erosion in some of the present-day onshore areas.

from peak positions on the XRD diffractograms (Hillier 2000) and the amounts were semi-quantitatively determined as major and minor phases.

\section{Petrographic analysis}

Polished thin sections were prepared from sandstone samples using blue epoxy for the impregnation to help the identification of open pore space. Half of each thin section was etched and stained with sodium cobaltinitrite for K-feldspar identification. Quantitative point counting was made by identifying 300 mineral grains in each thin section by the use of a petrographic microscope with polarisation filters. The open pore spaces were also counted.

SEM analyses of sandstones were made on a Philips XL40 SEM equipped with Thermo Nanotrace and Pioneer Voyager energy dispersive X-ray (EDX) detec- tors. EDX was used for making elemental analyses of the grains to give a semi-quantitative identification of the minerals. The SEM analyses were performed on carboncoated thin sections and gold-coated rock chips placed on carbon tape.

\section{Principal component analysis}

Multivariate data analysis was used to classify the lithology types according to their elemental composition by applying principal component analysis (PCA). The PCA transforms a matrix of measured data $\mathrm{X}(\mathrm{N}$ samples, $\mathrm{P}$ variables) into sets of projection sub-spaces. These are delineated by principal components that are each a linear combination of all $P$ variables and display variance-maximised interrelationships between samples and variables, respectively (Esbensen 2010). PCA score plots display groupings between samples based on compositional 

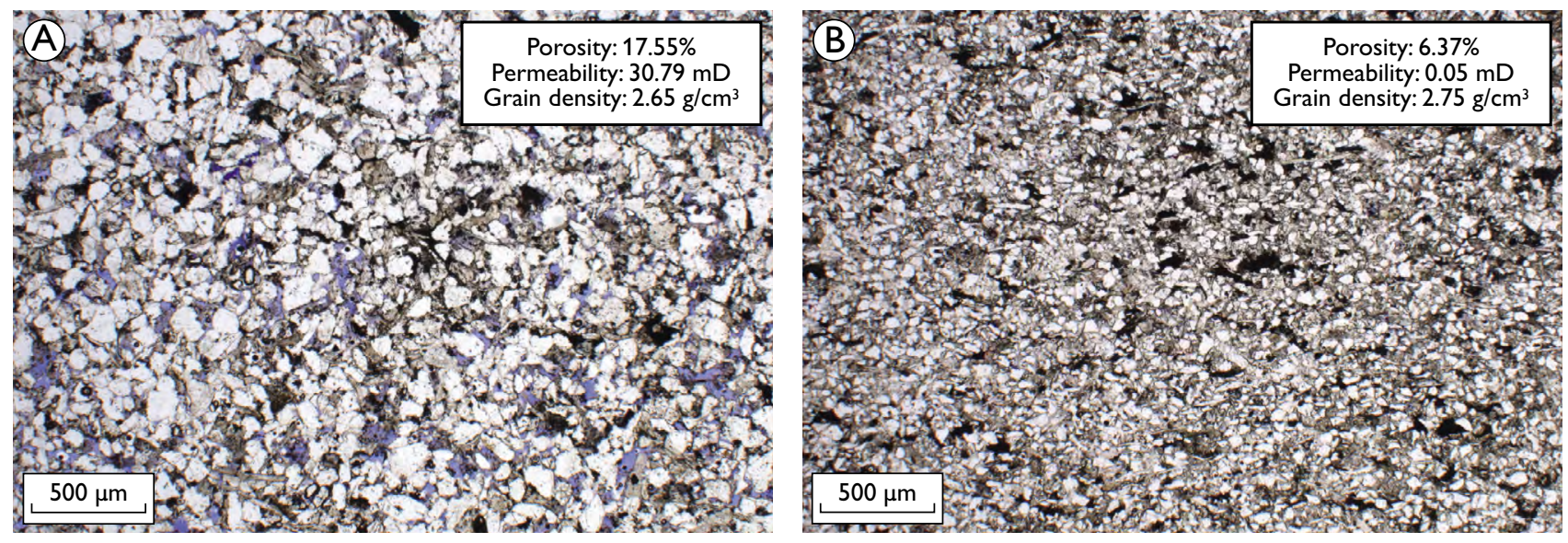

Fig. 4. Typical textures of sandstones from the Hareelv Formation. A: Fine-grained sandstone with open pores indicated by blue epoxy coloration. B: Very fine-grained sandstone with pervasive ankerite cementation. In general, high porosities and intermediate to high permeabilities are present in the fine- and medium-grained sandstones, whereas the very fine-grained sandstones contain pervasive ankerite cement and thus show poor reservoir quality.

similarities, as described by the variable correlations that are shown in accompanying loading plots. Furthermore, the proportion of total data-set variance that can be modelled by each component is quantified. All data analyses in this study are based on auto-scaled data [X-X (avr)/ std]. The elements W, Co and Ta are excluded from the PCA since the values are misleading due to contamination from the tungsten carbide mortar. This contamination is rock-type specific since it was greatest for the silica-rich sandstones as they are harder than ankeritecemented sandstones and mudstones.

\section{Results}

Overall, there is good correlation between the mineralogy measured by bulk XRD and that obtained by point counting of thin sections (Figs 5, 6), but it should be noted that the XRD results are in wt $\%$ and the petrographic results are in vol\%. However, the amount of quartz is always higher in the XRD results than in the petrographic results ( $8 \%$ higher on average), whereas the amounts of clays, micas and feldspars are generally lowest in the XRD results. The three XRD analyses of bulk and clay fraction from 223.5, 221.2 and $218.8 \mathrm{~m}$ depth were carried out on samples from the base, middle and top, respectively, of the same turbiditic sandstone layer and show similar mineralogies (Figs 2, 5).

\section{Mineralogical composition}

The average quartz content of the sandstones is $66 \mathrm{wt} \%$ according to the $\mathrm{XRD}$ results, whereas quartz comprises $17 \mathrm{wt} \%$ of the mudstones (Fig. 5). Point counting shows that the detrital quartz grains are chiefly monocrystalline. Authigenic quartz on average comprises $5 \%$ of the sandstones and $9 \%$ of the total quartz content (Fig. 6), but the content of authigenic quartz is probably underestimated since microquartz could not be identified during point counting. The amount of authigenic quartz is constant up through the core whereas the clay content in the sandstones decreases upwards and is approximately halved from bottom to top. The sum of clay and mica minerals is $14 \mathrm{wt} \%$ on average for the sandstones and 69 wt $\%$ for the mudstones (Fig. 5). The amount of clay minerals usually exceeds the amount of mica minerals, and muscovite is the most common mica mineral (Fig. 6).

The feldspars amount on average to $9 \mathrm{wt} \%$ in the sandstones and mudstones, and albite is more abundant than K-feldspar (Fig. 5, Table 1). The albite content shows a weak upward increase in the cored sandstones. Some of the feldspar that is identified as albite in the XRD Rietveld quantification consists of low-Ca plagioclase as revealed by SEM EDX analysis. Pyrite amounts on average to $1 \mathrm{wt} \%$ in the sandstones and $6 \mathrm{wt} \%$ in the mudstones (Fig. 5). The EDX analyses confirm the XRD results, which show that ankerite is the only carbonate mineral in the sediments. The amount of ankerite is $<1 \mathrm{wt} \%$ in the mudstones, but large variations in abundance (0-41 wt $\%)$ are found in the sandstones (Fig. 5). The highest 

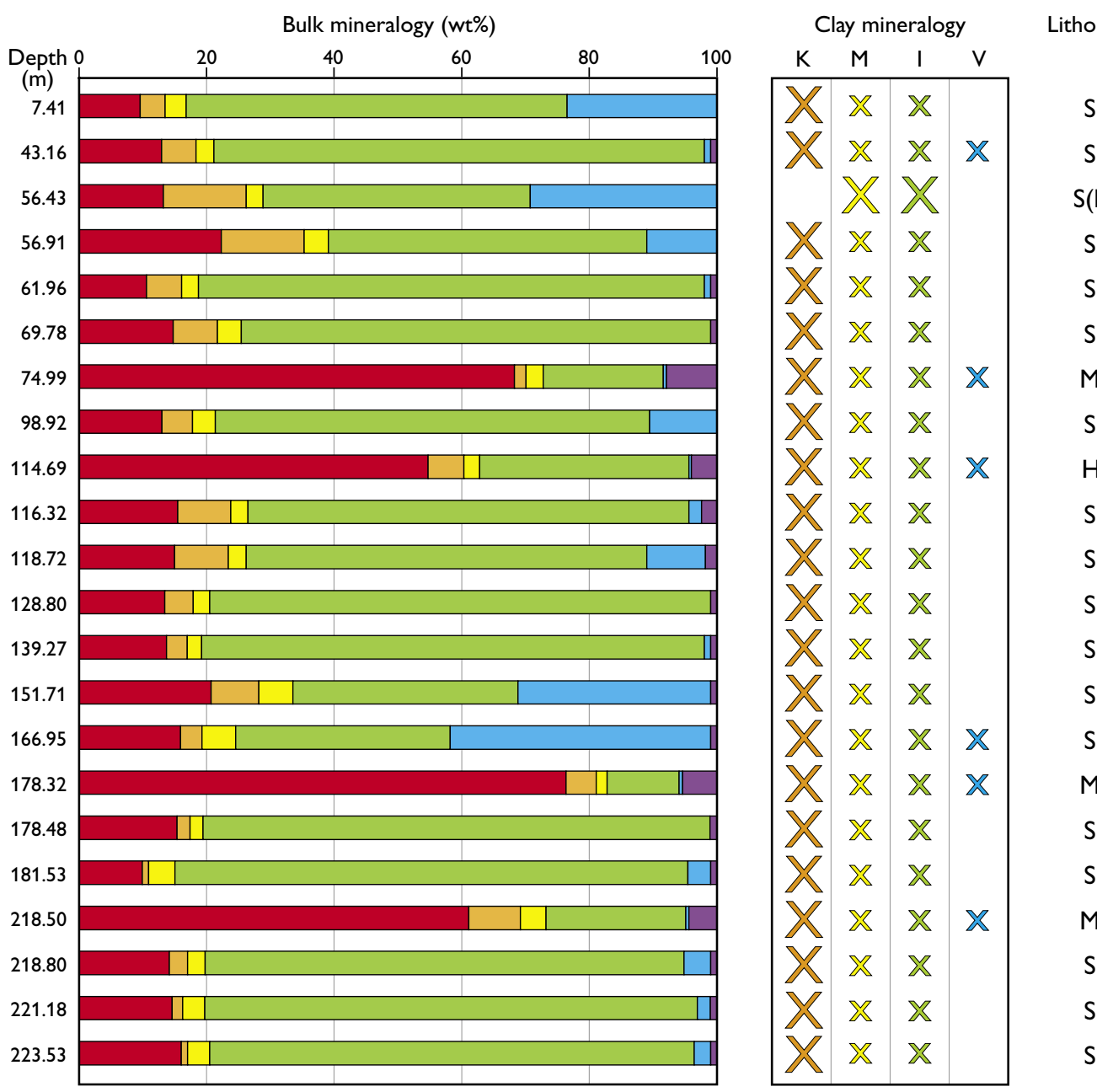

Bulk mineralogy
$\square$ Clays, micas
$\square$ Albite
$\square$ K-feldspar
$\square$ Quartz
$\square$ Ankerite
$\square$ Pyrite
Clay mineralogy
X Kaolinite
$\mathbb{X}$ Mixed-layer
XIllite
X Vermiculite
Clay quantity
Xajor phase
X Minor phase
S(I) Sandstone
(near intrusion)
L Heterolith
Mudstone

Fig. 5. Bulk and clay mineralogy of samples from the Blokelv-1 core measured by X-ray diffraction (XRD). The bulk mineralogy was quantified by the Rietveld method (Rietveld 1969). The clay mineralogy is semi-quantitatively determined as major and minor phases.

contents of organic matter are present in ankerite-cemented sandstones (Fig. 6). High ankerite content in the sandstones correlates with high feldspar content and low quartz content (Table 1). The average feldspar/quartz weight ratio is 0.09 in sandstones with $<5 \mathrm{wt} \%$ ankerite, 0.19 in sandstones containing $5-25 \mathrm{wt} \%$ ankerite, 0.33 in sandstones with $>25 \mathrm{wt} \%$ ankerite, and 0.45 in the analysed mudstones. The grain size of the sandstones correlates inversely with the ankerite content so a large amount of ankerite equates to a small grain size and vice versa (Table 1).

Kaolinite is the dominant clay mineral in all lithologies, but it is absent in one sandstone sampled adjacent to an igneous intrusion where illite and mixed-layer clays dominate (Fig. 5). Mixed-layer clays and illite are present in all lithologies. Vermiculite is present in the mudstones and the heterolith that were analysed, but only in two of the sandstones.

\section{Geochemical composition}

The first two principal components in the PCA model resolve $82 \%$ of the total variance in the bulk geochemical data (Fig. 7A). The main trend is expressed by the $\mathrm{PC} 1$ axis and represents the variation in clay versus silica content, as seen by high positive PC1 loadings for element like $\mathrm{Al}_{2} \mathrm{O}_{3}, \mathrm{~K}_{2} \mathrm{O}$ and most trace elements, and high negative values for $\mathrm{SiO}_{2}$. The PC2 axis displays high positive loadings of $\mathrm{CaO}, \mathrm{MgO}$ and $\mathrm{MnO}$ and high negative loadings of $\mathrm{SiO}_{2}$, which reflect the variation in carbonate 
Table 1. Mineral content and feldspar/quartz ratios versus lithology and ankerite content

\begin{tabular}{r|c|c|c|c|c}
\hline & \multicolumn{3}{|c|}{ Sandstone } & Mudstone \\
& $<5$ wt\% & $5-25$ wt\% & $>25$ wt $\%$ & $<1$ wt\% \\
\hline Clay and mica (wt\%) & 13.7 & 15.0 & 16.6 & 68.6 \\
Albite (wt\%) & 3.8 & 7.5 & 7.9 & 4.9 \\
K-feldspar (wt\%) & 3.0 & 3.4 & 4.4 & 2.8 \\
Quartz (wt\%) & 76.8 & 60.1 & 36.9 & 17.3 \\
Ankerite (wt\%) & 1.6 & 13.6 & 33.4 & 0.5 \\
Pyrite (wt\%) & 1.1 & 0.5 & 0.7 & 5.9 \\
Feldspar/quartz ratio & 0.09 & 0.19 & 0.33 & 0.45 \\
Grain size ( $\mu \mathrm{mm})$ & 185 & 159 & 105 & \\
Number of samples & 11 & 4 & 3 & 3 \\
\hline
\end{tabular}

The values are averaged from bulk XRD analyses.

versus silica content that is associated with carbonate cementation in some of the sandstones.

The different lithologies are clearly separated on the PCA score plot (Fig. 7B). The sandstones are characterised by negative $\mathrm{PC} 1$ score values and the carbonatecemented parts ( $>5 \%$ ankerite) have positive PC2 score values. The mudstones have the highest PC1 scores, reflecting the highest clay and lowest silica content, and the heteroliths have intermediate PCA score values compared to sandstone and mudstones, as expected from their intermediate composition.
It is evident from the PC2 score values that the mudstones are not cemented with ankerite whereas the heteroliths may be slightly ankerite-cemented (Fig. 7B). The large amounts of $\mathrm{Zr}$, Hf and $\mathrm{Na}_{2} \mathrm{O}$ in the ankerite-cemented sandstones show that they contain more zircon and albite than the uncemented sandstones. Correlation between ankerite-cemented sandstones and $\mathrm{Fe}_{2} \mathrm{O}_{3}$ is not evident due to the high pyrite content of the mudstones.

\section{Reservoir properties}

A moderately good correlation $\left(\mathrm{R}^{2}=0.79\right)$ exists between porosity and air permeability in the sandstones of the Blokelv-1 core (Fig. 8). In general, permeabilities lower than the trendline are related to finer-grained sandstones while permeabilities above the trendline are associated with coarser-grained sandstones. The lowest porosities and air permeabilities of $6.4-9.6 \%$ and $0.05-0.21 \mathrm{mD}$, respectively, are found in two ankerite-cemented sandstones which are also characterised by high grain densities of $2.75 \mathrm{~g} / \mathrm{cm}^{3}$ (Fig. 8). The remaining sandstones without significant ankerite cementation have grain densities of $2.62-2.69 \mathrm{~g} / \mathrm{cm}^{3}$, porosities of $14.3-25.7 \%$ and air permeabilities of $0.3-411.9 \mathrm{mD}$. The inter-granular volume (IGV) is the sum of porosity and authigenic miner-

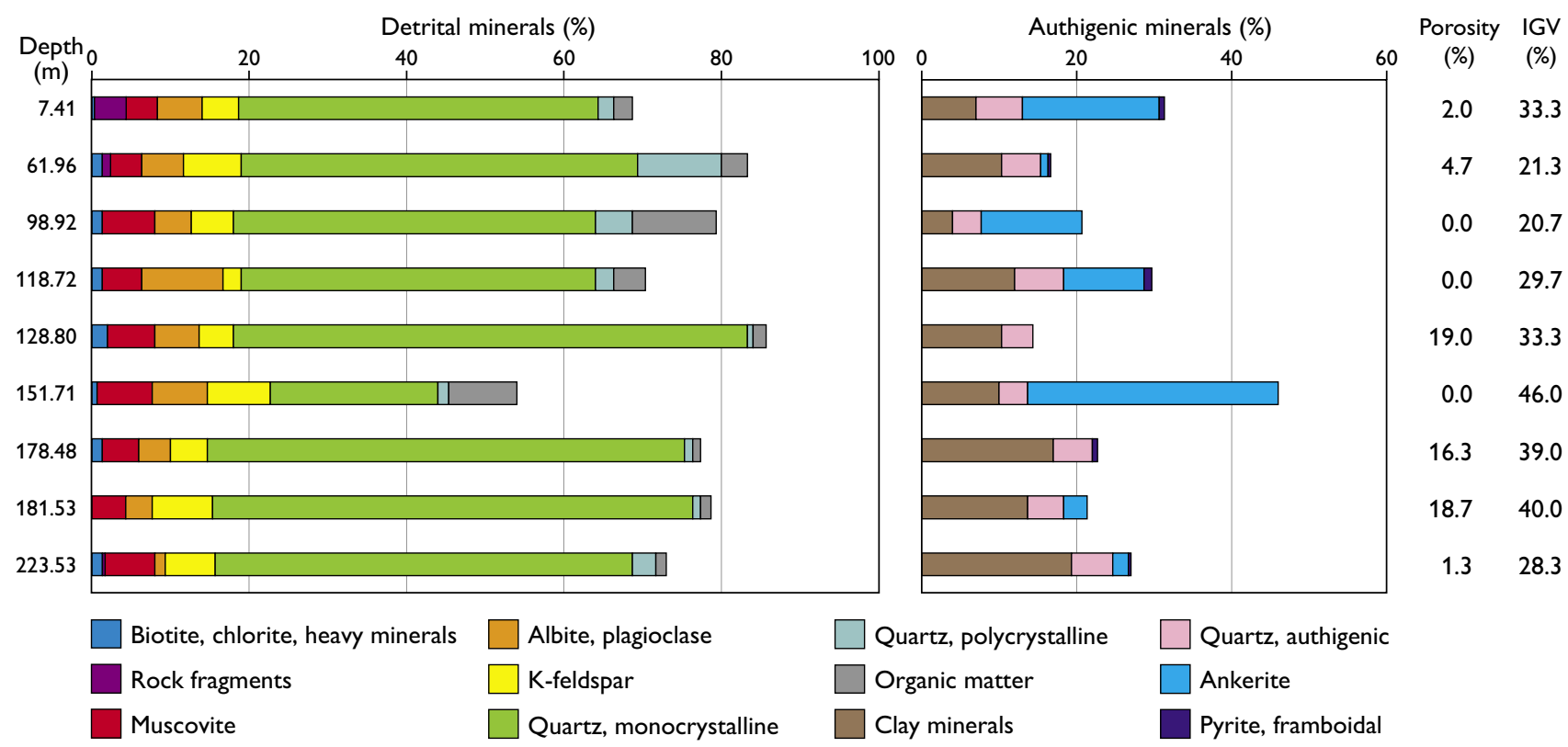

Fig. 6. Quantitative bulk mineralogy of sandstones from the Blokelv-1 core determined by point counting. The detrital and authigenic minerals are summed to $100 \%$; the sum of porosity and authigenic minerals constitutes the inter-granular volume (IGV). 

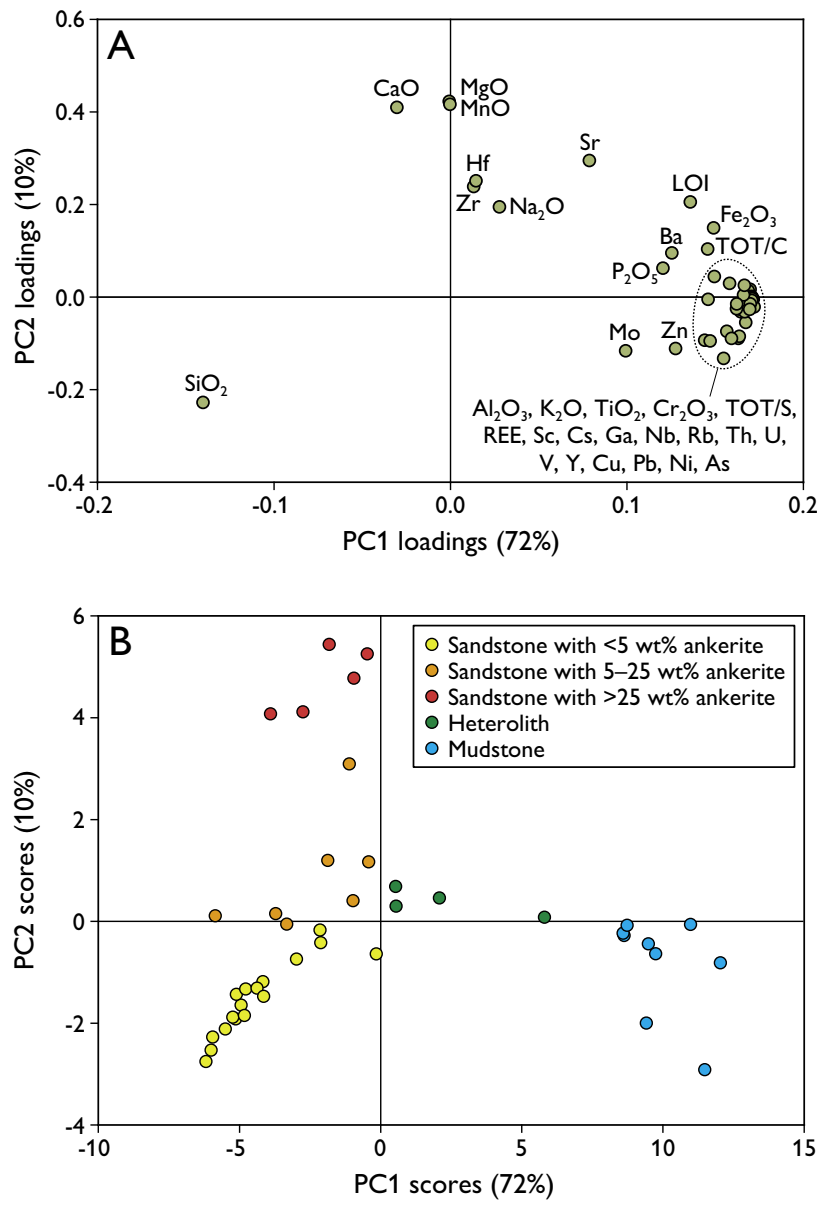

Fig. 7. Results of multivariate data analysis (principal component analysis, PCA) based on bulk geochemical analyses of the Blokelv-1 core (data from Bjerager $e$ al. 2018a, this volume). The first and second principal components (PC) are shown. A: On the loading plot, the elements cluster according to their mineralogical association. B: The score plot shows clear separation between each lithology class based on its score value. The sandstones are subdivided by their ankerite content, which was determined by XRD for 18 of the samples.

als (Houseknecht 1987; Ehrenberg 1989) and it amounts to $21-46 \%$ in the point-counted sandstones (Fig. 6).

The ankerite-cemented sandstone intervals are clearly recognisable on the bulk-density log due to the high grain density of ankerite (Fig. 9). It is evident from the bulk-density log that extensive metre-thick, ankerite-cemented sandstone intervals occur immediately adjacent to sandstones with a low degree of ankerite cementation.
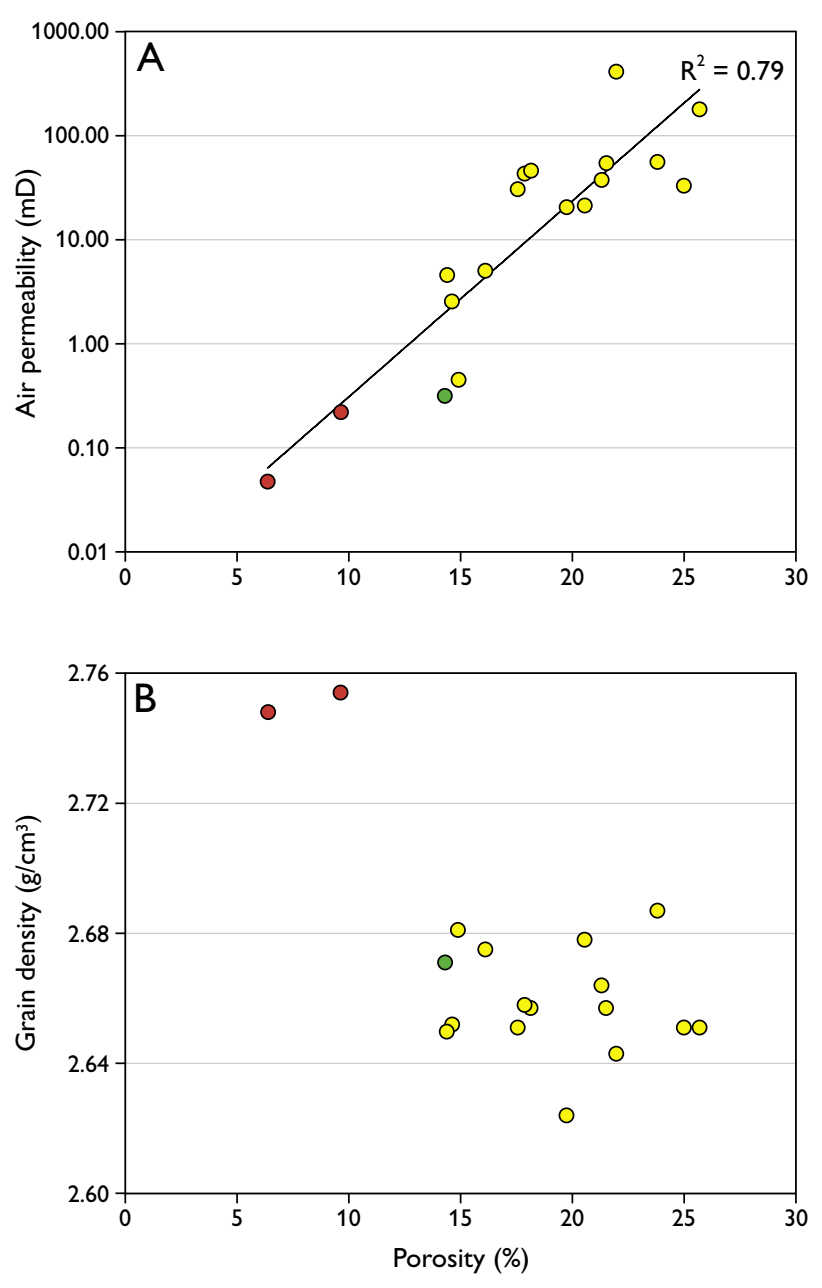

O Sandstone with no or patchy ankerite cement - Sandstone with pervasive ankerite cement O Sandstone near igneous intrusion

Fig. 8. He-porosity versus air-permeability (A) and grain density (B) of sandstone samples from the Hareelv Formation (Bjerager et al. 2018a, this volume). The ankerite-cemented sandstones have the lowest porosity and permeability and the highest grain density of all samples. Relatively low porosities and permeabilities are also observed in sandstones that have been affected by igneous intrusions, whereas the variation in the remaining sandstones is caused by a combination of microquartz coatings and clay minerals.

The porosity and permeability logs show that porosity and especially permeability are low in the ankeritecemented sandstones. The values are reduced in sandstones above and below cemented intervals as compared to sandstone beds that do not have any intervals with pervasive ankerite cementation and therefore typically have porosities greater than $18 \%$ and permeabilities above 10 $\mathrm{mD}$ (Fig. 9). 

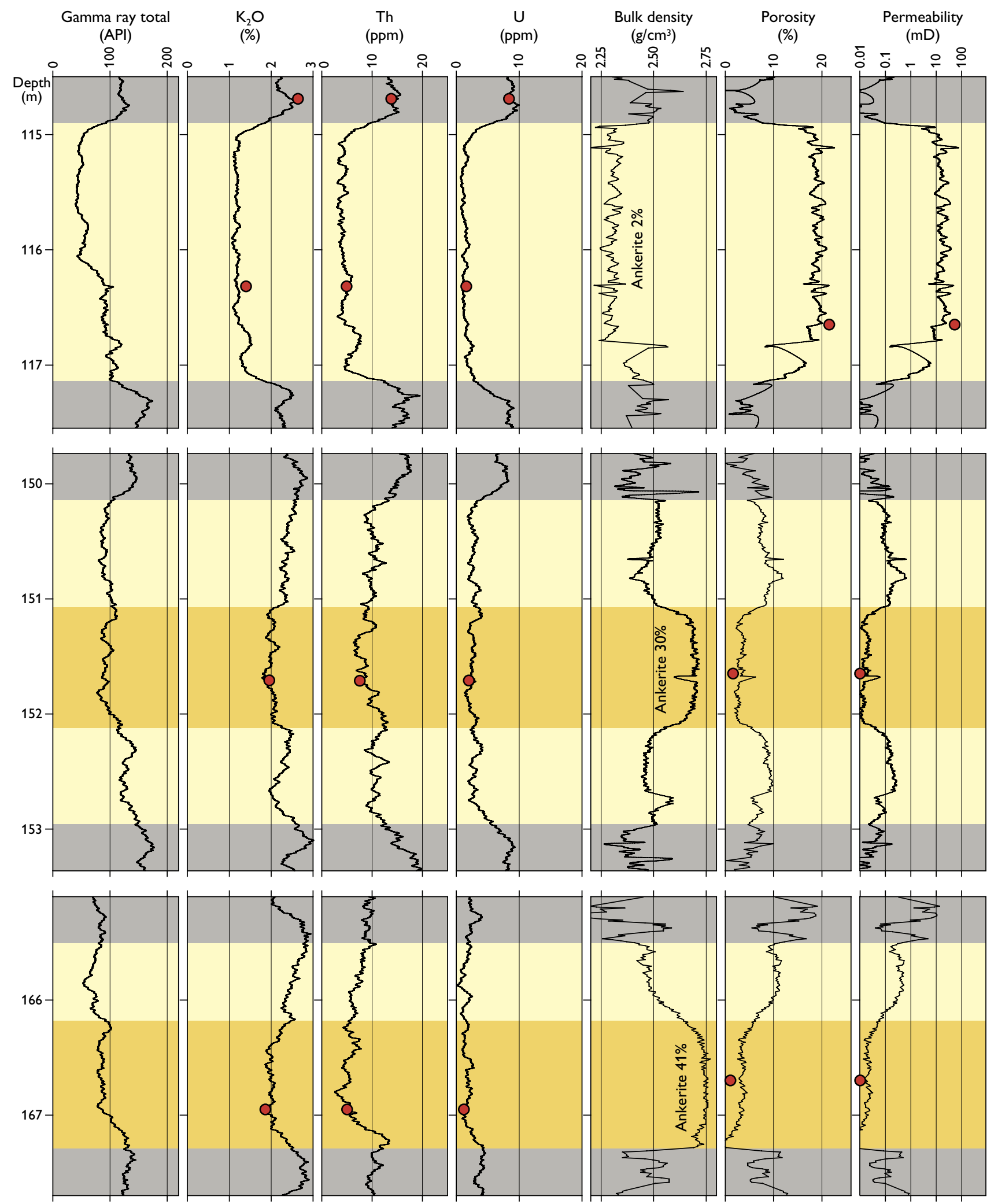

Sandstone

Sandstone (ankerite-cemented)

Mudstone/heterolith

Core measurement

Fig. 9. High-resolution profile of the core spectral gamma ray $\left(\mathrm{GR}_{\text {Total }}, \mathrm{K}, \mathrm{Th}, \mathrm{U}\right)$ and bulk density log with the derived porosity and permeability logs (Bjerager et al.2018a, this volume) for three selected intervals of the Blokelv-1 core. The ankerite contents were determined by point counting of thin sections and show that ankerite-cemented beds are characterised by a bulk density of about $2.75 \mathrm{~g} / \mathrm{cm}^{3}$. 


\section{Petrographic relationships}

The detrital components in the sandstones comprise quartz, albite, K-feldspar, mica minerals, rock fragments, heavy minerals and organic matter (Fig. 6). Furthermore, macroscopic mudclasts and bioclasts are often present within the sandstones (Fig. 2). Elongate detrital grains such as mica minerals are generally oriented parallel to the layering, and the mica grains are often bent around more resistant grains. Most of the organic matter in the pervasively ankerite-cemented sandstones consists of inertinite (Fig. 10A). The authigenic components in the sandstones mainly comprise microquartz, quartz overgrowths, ankerite, kaolinite, illite, Ti-oxides and pyrite. Pyrite framboids are common in the sandstones and are typically present within organic matter. Framboidal pyrite was also precipitated within muscovite grains prior to mica compaction.

Well-developed kaolinite booklets constitute the most common clay morphology (Figs 10B, C). Kaolinite is often present within and adjacent to albite grains and may fill large pore spaces (Fig. 10D). Kaolinite has grown locally between the cleavage planes of mica and beginning illitisation of kaolinite is observed (Fig. 10E). Kaolinite is often present around partly dissolved $\mathrm{K}$-feldspar grains, but not within the secondary pores; such K-feldspar dissolution has only occurred in some of the K-feldspar grains (Fig. 10F). Illite is the only mineral that has precipitated within the secondary porosity in some of the K-feldspar grains (Fig. 11A).

Microquartz often coats quartz and feldspar grains (Fig. 11B) and is often enclosed in other authigenic phases such as ankerite and illite. Quartz overgrowths are volumetrically small and the microquartz coatings apparently inhibited their formation. The quartz overgrowths are often interrupted and overgrown by illite (Fig. 11CD). Illite was precipitated later than microquartz, both simultaneously with and later than ankerite. Feldspar overgrowths are enclosed in the ankerite cement (Fig. 11E). Feldspars and muscovite have in some places been partly replaced by illite and mixed-layer clays. Mixed-layer clays constitute various combinations of clay minerals and can be difficult to recognise. Small amounts of $\mathrm{Ca}$ and $\mathrm{Na}$ are often found in the illite, however, and indicate the presence of mixed-layer clays such as smectite-illite.

Apatite has occasionally precipitated simultaneously with illite. Small Ti-oxide crystals have commonly formed simultaneously with illite within the clay (Fig. 11C). Precipitation of Ti-oxides was contemporaneous with the formation of euhedral pyrite, but continued after pyrite formation ceased. Euhedral pyrite crystals formed later than ankerite. Initial stylolitisation is observed in places along the numerous mica grains and organic matter.

Ankerite cement mainly precipitated simultaneously with macroquartz (Fig. 11C) and often formed around and within dissolving albite and plagioclase grains. The ankerite crystals are often zoned corresponding to an increasing Fe-content from core to rim whereas the Cacontent and especially the $\mathrm{Mg}$-content decrease. The ankerite cement is pervasive in some sandstone intervals, which are in general more fine-grained than the sandstones with less intensive cementation (Table 1). The poikilotopic ankerite replaced some of the quartz, feldspar and mica grains partly or fully (Fig. 11F). Partial albitisation of some of the K-feldspar and plagioclase grains occurred prior to the poikilotopic ankerite phase.

Four igneous intrusions are present in the cored succession at depths of 100.10-102.04, 55.20-56.40, 26.40-27.10 and 7.05-7.35 m (Fig. 2); they consist of sparsely plagioclase-olivine-phyric tholeiitic basalt (Fig. 12A; Larsen 2018, this volume). Three were intruded in sandstone intervals where they have affected the $\mathrm{di}$ agenesis of the adjacent sandstones, albeit only at a centimetre-scale. The changes involve a second episode of microquartz precipitation that formed on surfaces of macroquartz and ankerite simultaneously with continued illite and ankerite precipitation (Fig. 12B, C). Resumed quartz overgrowth subsequently enveloped some of the microquartz.

Ankerite-filled fractures up to $0.5 \mathrm{~mm}$ thick are present near some of the sandstone-basalt contacts (Fig. 12D). The fractures both cross-cut the contact or run parallel to the contact within the sandstone. The ankerite becomes more $\mathrm{Fe}$-rich towards the middle of the fractures where pyrite and cavities are sometimes present. Patches of pyrite are locally abundant in the sandstones near the intrusions (Fig. 12D). The groundmass of the basalts is partly altered in the chilled margins (Fig. 12A). Olivine is altered and partly dissolved within the chilled margins of the intrusions, whereas plagioclase is fresh (Fig. 12E; Larsen 2018, this volume). The Ba-feldspar celsian was recorded immediately above the thickest intrusion where it forms abundant crystals with sizes of 5-10 $\mu \mathrm{m}$ (Fig. $12 \mathrm{~F})$. Kaolinite is rare to absent in sandstones next to intrusions, whereas it is the dominant clay mineral in all other sandstones (Fig. 5). 

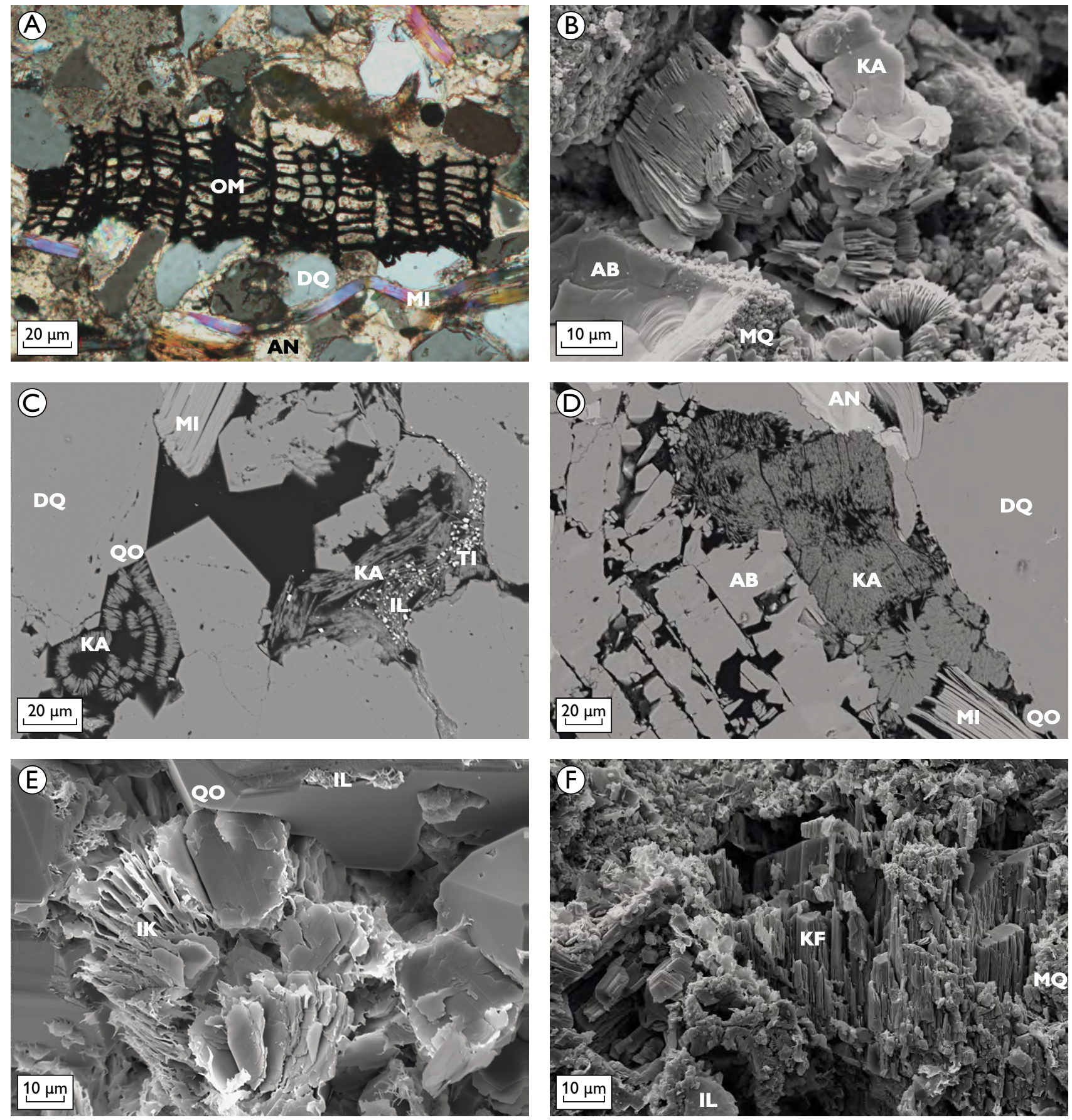

Fig. 10. Petrographic relationships in the Hareelv Formation sandstones. A: Inertinite enclosed in ankerite cement. Crossed nicols image, $151.71 \mathrm{~m}$. B: Pore-filling kaolinite booklets. Secondary electron image, $69.78 \mathrm{~m}$. C: Growth of kaolinite, macroquartz, illite and Ti-oxides. Backscatter electron image, $7.41 \mathrm{~m}$. D: Albite partially replaced by kaolinite. Backscatter electron image, $7.41 \mathrm{~m}$. E: Partial illitisation of kaolinite that is partly enclosed in macroquartz. Secondary electron image, $221.18 \mathrm{~m}$. F: Partly dissolved K-feldspar grains enclosed in microquartz and illite. Secondary electron image, $100.05 \mathrm{~m}$ (photo courtesy of Morten L. Hjuler). AB: albite. AN: ankerite cement. DQ: detrital quartz. IK: illitisation of kaolinite. IL: illite. KA: kaolinite. KF: K-feldspar. MI: mica. MQ: microquartz. OM: organic matter. QO: quartz overgrowth. TI: Ti-oxide. 


\section{Discussion}

No systematic mineralogical differences are found between the in situ and remobilised, intruded gravity-flow deposits, so the post-depositional remobilisation of some of the sandstones (Fig. 2) has not influenced the diagenesis. The similar mineralogical composition of the three deepest sandstone samples (Fig. 5), which were sampled at the base, middle and top of a single gravity-flow bed, indicates that no significant mineralogical variation is present within such a sandstone body. These results further indicate that diagenesis in the sand layers was independent of the distance to the bed margins with adjacent mudstone layers, suggesting that there was limited transport of dissolved solids in the pore water.

\section{Clay-mineral formation}

Authigenic kaolinite is present in the sandstones, but its formation is enigmatic in these marine basinal deposits since interaction with flowing fresh or brackish water, undersaturated in salt, is necessary for its formation (Bjørlykke 1998). Some of the kaolinite may be detrital, having formed in deltaic environments before the sand was transported to the basin floor by gravity flows, but at least some of the kaolinite booklets are so well preserved that they are likely to have formed in situ (Fig. 10C). It is not clear, however, how the authigenic kaolinite formed in this marine setting, especially as it is assumed to have formed shortly after deposition.

Kaolinite often formed in association with dissolution of albite grains, as testified by its location, filling large pore spaces next to partly dissolved albite grains (Fig. 10D). There is a weak upwards-decreasing trend in clay content in the cored sandstones accompanied by an upwards-increasing albite content (Figs 5, 6); this is also reflected by a pronounced upwards increase in the $\mathrm{Na}$ content (Bjerager et al. 2018a, this volume). It appears therefore that more kaolinite formed at the expense of albite in the lower part of the core relative to higher in the section. This may be explained by the gradual deepening of the depositional setting during the accumulation of the Katedralen Member (Surlyk 2003; Bjerager et al. 2018a, this volume), such that flushing of the gravity-flow sands with undersaturated water became progressively less likely as the water depth in the Jameson Land Basin increased and the shoreline transgressed. It is not clear, however, how such meteoric water penetrated far into the subsurface beneath the marine basin although it is possible that the geometry of the sand bodies favoured such a process.
The gravity-flow deposits of the Katedralen Member are interpreted to have been deposited in steep-sided gullies that terminated in sheet-sand splays on the basin floor (Surlyk et al. 2007). The gully-fill sands encased in impermeable muds may have channelled downward flow of undersaturated surface water.

An alternative explanation is that the kaolinite may have formed when much of the Jameson Land Basin was subaerially exposed in the latest Volgian (Surlyk \& NoeNygaard 2005). The accompanying flushing with meteoric water might have reached deep into the sediments if the porous sand beds and injectites formed conduits for the flow. It is unlikely that kaolinite formed during Cenozoic uplift since the low permeabilities caused by sandstone cementation, at least locally, and mudstone compaction and cementation would have precluded sufficient flow of undersaturated water. The igneous intrusions emplaced in the early Cenozoic would have constituted additional flow barriers.

Beginning illitisation of kaolinite is observed (Fig. $10 \mathrm{E}$ ) and illite sometimes formed in the partly dissolved K-feldspar grains (Fig. 11A), indicating that illite and quartz precipitated at the expense of kaolinite and $\mathrm{K}$ feldspar (Bjørlykke 2015). The presence of mixed-layer clays containing small amounts of $\mathrm{Na}$ and $\mathrm{Ca}$ suggests that some of the illite may have transformed from smectite (Fig. 5), and mixed-layer illite-smectite has been previously recorded from mudstones of the Hareelv Formation (Lindgreen \& Surlyk 2000).

\section{Ankerite formation}

The locally high ankerite content of up to $41 \mathrm{wt} \%$ (Fig. 5) shows that a volumetrically significant carbonate source must have been present within the sandstones. The clear correlation between grain size and ankerite content shows that ankerite precipitation was favoured in sandstones with a very fine grain size (Fig. 4, Table 1 ), probably because more biogenic carbonate mud was deposited in the finer-grained sediments, which then sourced carbonate cementation during burial. Mouldic ankerite-filled macropores are not observed in the sandstones so dissolution of larger carbonate clasts and fossils was probably not a significant source of carbonate.

Formation of carbonate cement at rather shallow depth prior to significant mechanical compaction is indicated by the locally high ankerite content, but the cement may first have precipitated as calcite and then have been replaced by ankerite at deeper burial. This seems plausible 

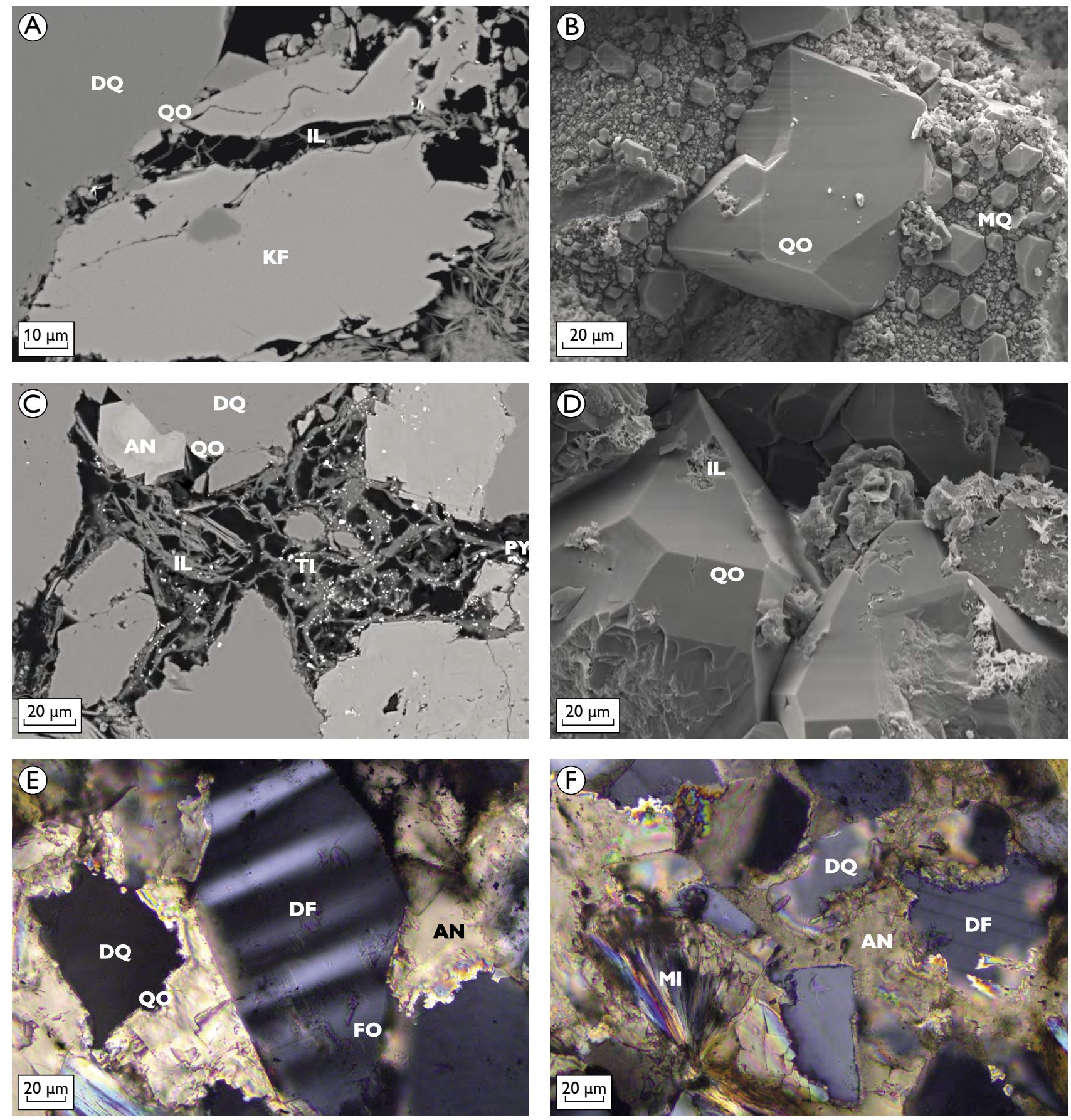

Fig. 11. Petrographic relationships in the Hareelv Formation sandstones. A: Illite precipitated within secondary porosity in K-feldspar. Backscatter electron image, $100.05 \mathrm{~m}$. B: Quartz overgrowth on the central grain surrounded by microquartz crystals of various dimensions. Secondary electron image, $43.16 \mathrm{~m}$. C: Grow th of ankerite and macroquartz was restricted by illite precipitation. Backscatter electron image, 7.41 $\mathrm{m}$. D: Macroquartz and illite have grown simultaneously. Secondary electron image, $221.18 \mathrm{~m}$. E: Feldspar and quartz overgrowths enclosed in ankerite. Crossed nicols image, $166.70 \mathrm{~m}$. F. Plagioclase, quartz and muscovite partly replaced by ankerite. Crossed nicols image, $151.71 \mathrm{~m}$. AN: ankerite cement. DF: detrital feldspar. DQ: detrital quartz. FO: feldspar overgrowth. IL: illite. KF: K-feldspar. MI: mica. MQ: microquartz. PY: pyrite. QO: quartz overgrowth. TI: Ti-oxide. 

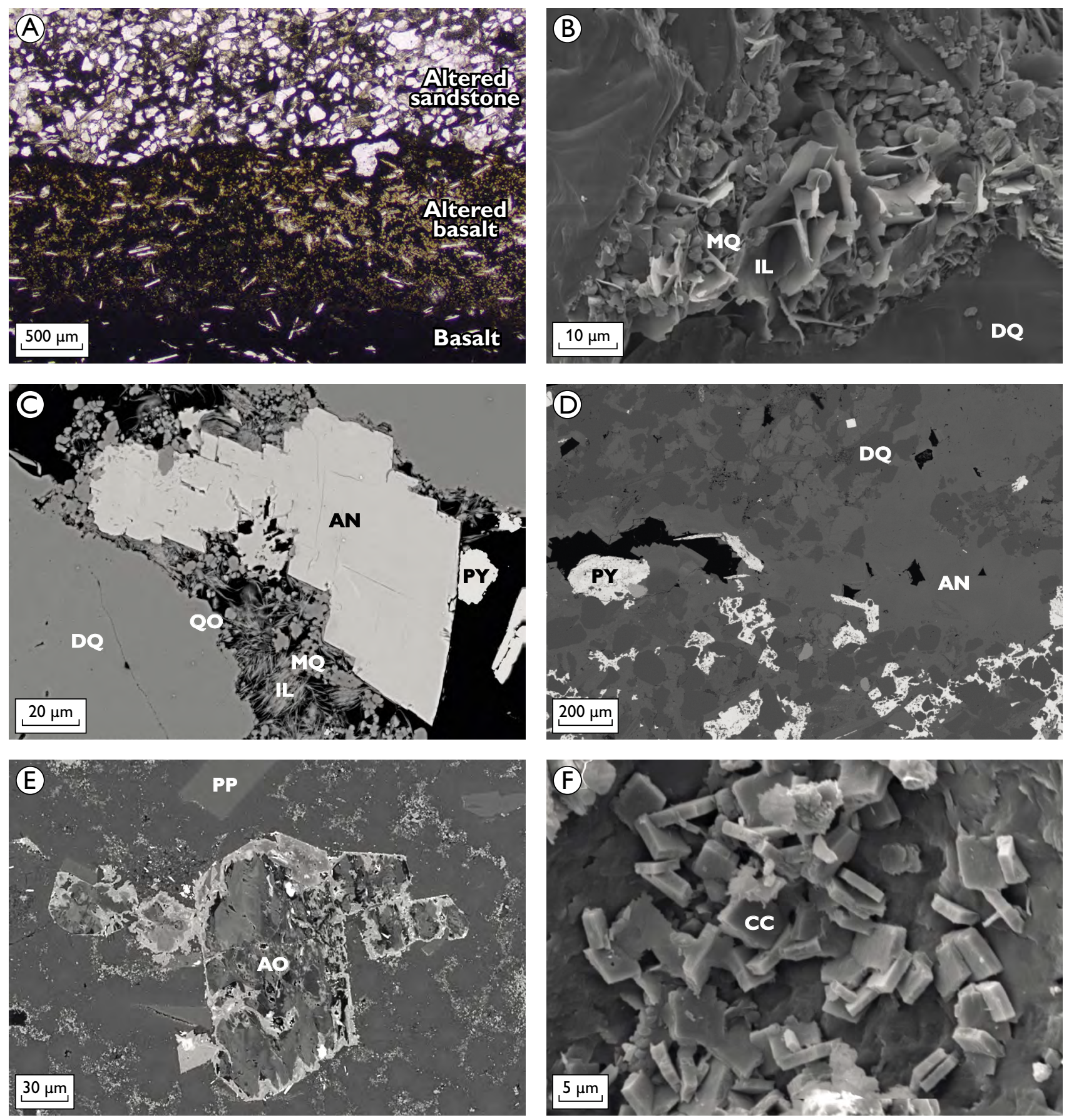

Fig. 12. Diagenesis induced by enhanced heat flow and altered pore-fluid composition near basaltic sills and dykes in the Hareelv Formation sandstones. A: Sandstone and basalt have been altered in the contact aureole. Direct light image, $55.20 \mathrm{~m}$. B: Microquartz and illite have grown simultaneously. Secondary electron image, $100.05 \mathrm{~m}$. C: Most ankerite grew before precipitation of microquartz and illite. Backscatter electron image, $100.05 \mathrm{~m}$. D: Ankerite and pyrite precipitated in pores and fractures near the intrusion. Backscatter electron image, $55.18 \mathrm{~m}$. E: Olivine was dissolved in the chilled edge of the basalt and ankerite was precipitated. Backscatter electron image, $55.20 \mathrm{~m}$. F: Abundant celsian crystals formed locally near the intrusion. Secondary electron image, $100.05 \mathrm{~m}$. AN: ankerite cement. AO: altered olivine. CC: celsian crystal. DQ detrital quartz. IL: illite. MQ: microquartz. PP: plagioclase phenocryst. PY: pyrite. QO: quartz overgrowth. 
since quartz and feldspar overgrowths are enclosed in the ankerite cement (Fig. 11E) and because such a replacement was presumably only possible once iron and magnesium had been released by the smectite to illite transition (Boles 1978). Although growing quartz crystals may displace carbonate cement, the ankerite probably formed late during burial because the ankerite crystals, including those that formed on quartz overgrowths, often become more Fe-rich towards their rim (Fig. 11C). $\mathrm{Ca}, \mathrm{Mg}$ and Mn correlate very well in the PCA model (Fig. 7) suggesting that these elements reside primarily in ankerite and can pinpoint the cemented intervals.

\section{Maximum burial depth}

The section removed by erosion is estimated to have been $2.8 \mathrm{~km}$ thick at the Blokelv- 1 borehole location based on apatite fission-track analyses (Green \& Japsen 2018, this volume); such burial corresponds to maximum palaeotemperatures of $c .100-105^{\circ} \mathrm{C}$ in the studied succession with a presumed palaeogeothermal gradient of $30^{\circ} \mathrm{C} / \mathrm{km}$. This is in agreement with the general interpretation of the magnitude of Cenozoic uplift of the Jameson Land Basin area (Mathiesen et al. 2000; Hansen et al. 2001) and fits well with the diagenetic changes observed in the present study.

The presence of kaolinite and mixed-layer clays sets limits on the maximum possible temperature that the sediments can have been subjected to, since kaolinite is unstable in the presence of K-feldspar at temperatures above $c .130^{\circ} \mathrm{C}$ (Bjørlykke et al. 1986; Bjørlykke 1998). The rather small amount of authigenic quartz in the studied sandstones (Fig. 6) is a result of the porosity-preserving effect of the microquartz coatings and the limited residence time at deepest burial, which occurred prior to the onset of late Eocene uplift (Green \& Japsen 2018, this volume).

Bending of mica around harder detrital grains occurred during mechanical compaction (Fig. 10A), but no grain crushing or pressure dissolution of quartz grains parallel to the layering have been observed. Incipient stylolitisation along concentrations of mica grains and organic matter is present in some of the sandstones. Stylolite formation in sandstones generally initiates at around $2.5 \mathrm{~km}$ of burial and well-developed stylolites are typically formed at depths of $>3.5 \mathrm{~km}$ (Bjørlykke $e$ t al. 1986). Fully developed stylolites have been reported in Jurassic sandstones of the Vardekløft Group in outcrops on Traill $\varnothing$ in East Greenland (Baron \& Parnell 2007), but they may have formed in response to heating by igneous intrusions at a presumed burial depth of $2.0-2.5 \mathrm{~km}$ (Therkelsen 2016). However, the incipient stylolitisation in the Hareelv Formation appears to be unrelated to igneous intrusions and has thus presumably developed in response to elevated temperatures during burial.

\section{Intrusion-induced diagenesis}

Two basalt sills and one dyke with thicknesses of up to $1.9 \mathrm{~m}$ were intruded into sandstone intervals in the cored succession during the early Eocene (Fig. 2; Larsen 2018, this volume). One sill of $0.7 \mathrm{~m}$ thickness intruded into a mudstone interval in which the thermal maturity is significantly enhanced within a few metres of the intrusion (Bojesen-Koefoed et al. 2018, this volume). In the sandstones, intrusion-induced mineralogical changes are only evident up to a metre from the intrusions, and the enhanced heat flow caused by the intrusions may have been highly localised as the intrusions are so thin. Ba-feldspar (celsian) can precipitate during hydrothermal activity and low-grade metamorphism (Moro et al. 2001). Thus, the restricted occurrence of celsian close to one of the igneous intrusions (Fig. 12F) suggests that the sandstone was subjected to high temperatures immediately adjacent to the intrusion.

Microquartz usually forms under shallow burial and requires the pore fluids to be supersaturated relative to quartz (Jahren \& Ramm 2000). Thus, the second episode of microquartz precipitation that occurred in the deeply buried sandstones near intrusions (Figs 12B, C) resulted from silica supersaturation in the pore fluids induced by interaction with the intrusions. All olivine crystals have been altered in the chilled margins of the intrusions (Fig. $12 \mathrm{E}$; Larsen 2018, this volume) and this alteration probably represents the source of the Si-enrichment as ankerite is often observed within the dissolved olivine crystals. This fresh supply of iron and magnesium from dissolved olivine was presumably what promoted precipitation of ankerite and pyrite in the contact aureoles of the intrusions. Precipitation of ankerite must have occurred rapidly in the fractures created by the intrusions before the fractures were closed by mechanical compaction (Fig. 12D). The pore fluids became increasingly more Fe-rich, as recorded by the outwards-increasing $\mathrm{Fe}$-content in zoned ankerite crystals.

Kaolinite is not present near the intrusions in contrast to all other sandstones in the core; this indicates that the locally high temperatures near the intrusions caused kao- 


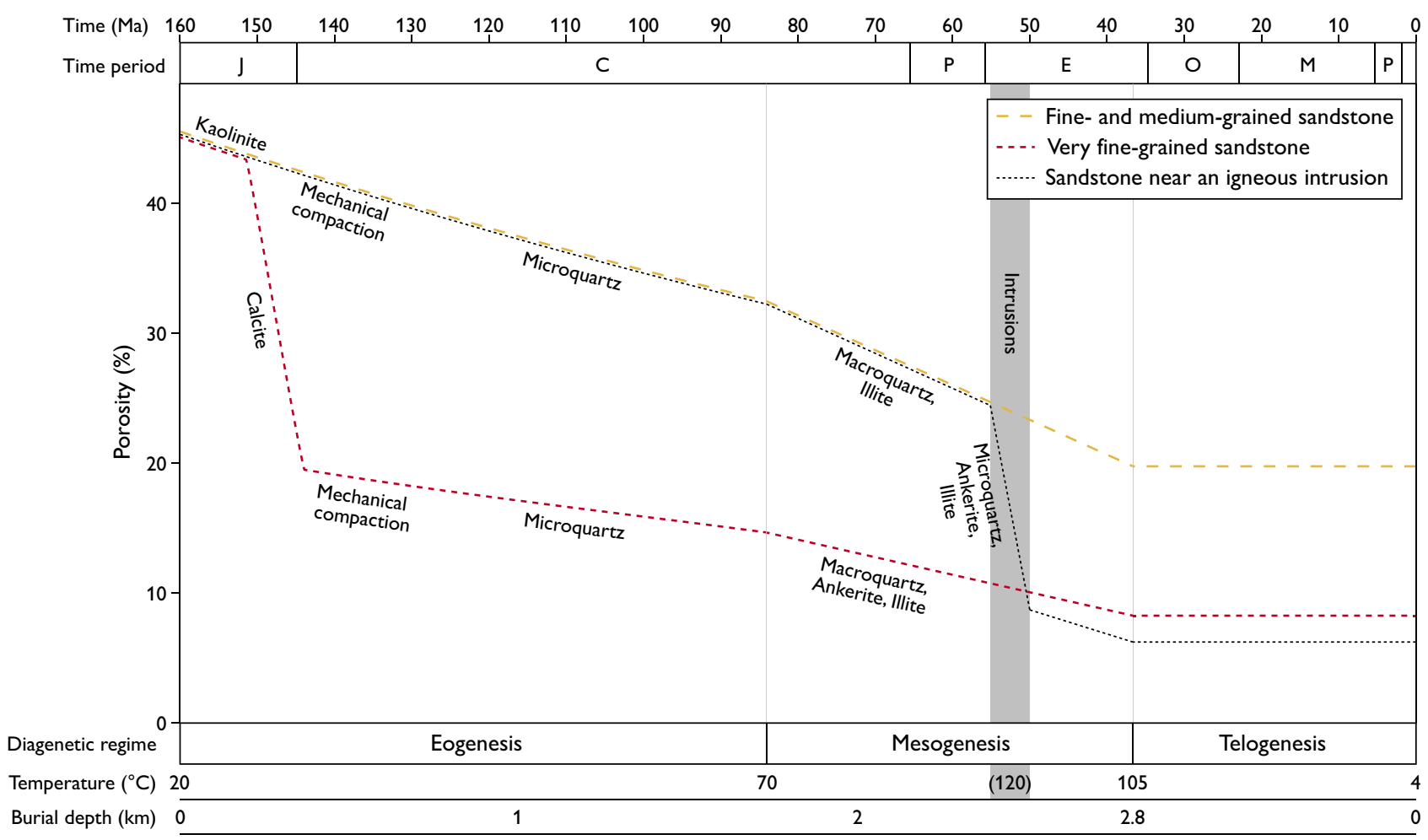

Fig. 13. Tentative porosity evolution and diagenetic development of the Hareelv Formation sandstones. The correlation between burial and time is derived from apatite fission-track analyses (Green \& Japsen 2018, this volume); the timing of igneous intrusion is from Larsen (2018, this volume). The mechanical compaction curve is based on a study of microquartz-coated sandstones (Ramm et al. 1997); the onset of mesogenesis, where chemical compaction succeeds mechanical compaction, is estimated at about $70^{\circ} \mathrm{C}$ (Morad et al. 2000). The presence and timing of early calcite cement is uncertain. The present-day porosity of the three sandstone classes illustrated is taken as an average of the analysed representatives.

linite to be altered to illite, explaining the increased illite content near the intrusions despite a total clay content that is similar to sandstones elsewhere in the cored section.

\section{Reservoir quality}

A tentative porosity development during burial is presented in Fig. 13 concerning those diagenetic changes that most affected the porosity. The timing of the precipitation of the various minerals is determined by their petrographic relationships to known processes of mineral alteration. However, the timing of kaolinite precipitation and the presence and timing of an early calcite cement are uncertain.

The porosity is high in the uncemented sandstones in the Blokelv-1 core (Fig. 8), but some of it is present as microporosity in low-permeable clay minerals. Thus, the permeability ranges from intermediate to high, also because the sandstones are generally fine-grained ( $\mathrm{Ta}$ ble 1; Beard \& Weyl 1973). Porosities $>20 \%$ are only encountered in the upper $130 \mathrm{~m}$ of the core (Bjerager $e t$ al. 2018a, this volume), most likely due to the upwardsdecreasing clay content in the sandstones (Fig. 6). Pervasive ankerite precipitation is the diagenetic process that has most significantly reduced porosity and permeability (Figs 8,9), but the largest amounts of ankerite formed in the sandstones that already at deposition had the lowest permeability due to their very fine grain size (Table 1).

The highest porosities are present in the most quartzrich sandstones (Fig. 6) where microquartz coatings inhibited the precipitation of macroquartz. The sandstones were deeply buried for a limited period of time (Fig. 13; Green \& Japsen 2018, this volume), so the formation of quartz overgrowths and illite had not decreased reservoir quality critically (Fig. 8). The igneous intrusions reduced the porosity significantly in the contact aureoles of the 
adjacent sandstones due to the mineralogical changes caused by the enhanced heat flux and altered pore-fluid composition (Fig. 13). This is a strictly local phenomenon, however, since the influence is minimal in sandstones more than a metre away from the intrusions.

Most of the IGV values give an unrealistically low estimate of the depositional porosity (Fig. 6), which is mainly due to mechanical compaction (Houseknecht 1987; Ehrenberg 1989). In addition, porosity is underestimated during point counting when microporosity is present, as reflected by the higher values measured by core analysis (Fig. 8; Dutton \& Loucks 2010; Olivarius et al. 2015). Values of the calculated permeability log are overestimated in the mudstones (Fig. 9) because the calculation of permeability is based on the total porosity including microporosity, which does not increase permeability.

The cored sandstone layers are rather thin (Fig. 2), but they presumably have good vertical connectivity since most of them are remobilised (Bjerager et al. 2018a, this volume). Thus, the reservoir quality of the sandstones is intermediate to good in the intervals that lack pervasive ankerite cement and abundant clay minerals.

\section{Conclusions}

The dominant diagenetic changes that have occurred in the sandstones of the Hareelv Formation in the Jameson Land Basin comprise precipitation of kaolinite, microquartz, ankerite, macroquartz and illite. The largest porosity reduction was caused by pervasive ankerite, which formed in sandstones that already at the time of deposition had the lowest permeability due to their very fine grain size. In general, the porosity of the remaining sandstones is high and the permeability is intermediate to high since microquartz coatings have inhibited macroquartz formation, although some of the sandstones have poorer reservoir quality due to the presence of clay minerals. Igneous intrusions have lowered the porosity and permeability significantly in the closely adjacent sandstones where the primary diagenetic changes induced by the intrusions include renewed microquartz precipitation and accelerated formation of ankerite and illite.

\section{Acknowledgements}

The authors wish to thank Helene Almind, Kirsten Fries, Karen Henriksen, Anders Pilgaard and John Boserup for sampling and analysis. Valuable advice by Lotte
M. Larsen, Tonci Balic-Zunic, Holger Lindgreen and Morten Bjerager is much appreciated as well as artwork by Jette Halskov and Stefan Sølberg. The referees, Knut Bjørlykke and Jens Therkelsen, are thanked for insightful comments that improved the manuscript significantly.

\section{References}

Alsen, P. \& Piasecki, S. 2018: Biostratigraphy of the Hareelv Formation (Upper Jurassic) in the Blokelv-1 core, Jameson Land, central East Greenland. In: Ineson, J. \& Bojesen-Koefoed, J.A. (eds): Petroleum geology of the Upper Jurassic - Lower Cretaceous of East and North-East Greenland: Blokelv-1 borehole, Jameson Land Basin. Geological Survey of Denmark and Greenland Bulletin 42, 15-37 (this volume).

Baron, M. \& Parnell, J. 2007: Relationships between stylolites and cementation in sandstone reservoirs: Examples from the North Sea, U.K. and East Greenland. Sedimentary Geology 194, 17-35.

Beard, D.C. \& Weyl, P.K. 1973: Influence of texture on porosity and permeability of unconsolidated sand. AAPG Bulletin 57, 349-369.

Bjerager, M., Alsen, P. Bojesen-Koefoed, J.A., Piasecki, S. \& Pilgaard, A. 2018b: Late Jurassic evolution of the Jameson Land Basin, East Greenland - implications of the Blokelv-1 borehole. In: Ineson, J. \& Bojesen-Koefoed, J.A. (eds): Petroleum geology of the Upper Jurassic - Lower Cretaceous of East and North-East Greenland: Blokelv-1 borehole, Jameson Land Basin. Geological Survey of Denmark and Greenland Bulletin 42, 149-168 (this volume).

Bjerager, M., Kjøller, C., Olivarius, M., Olsen, D. \& Schovsbo, N. 2018a: Sedimentology, geochemistry and reservoir properties of Upper Jurassic deep marine sediments (Hareelv Formation) in the Blokelv-1 borehole, Jameson Land Basin, East Greenland. In: Ineson, J. \& Bojesen-Koefoed, J.A. (eds): Petroleum geology of the Upper Jurassic - Lower Cretaceous of East and North-East Greenland: Blokelv-1 borehole, Jameson Land Basin. Geological Survey of Denmark and Greenland Bulletin 42, 39-64 (this volume).

Bjørlykke, K. 1998: Clay mineral diagenesis in sedimentary basins - a key to the prediction of rock properties. Examples from the North Sea Basin. Clay Minerals 33, 15-34.

Bjørlykke, K. 2015: Petroleum Geoscience. From sedimentary environments to rock physics, 650 pp. Berlin, Heidelberg: Springer Verlag.

Bjørlykke, K., Aagaard, P., Dypvik, H., Hastings, D.S. \& Harper, A.S. 1986: Diagenesis and reservoir properties of Jurassic sandstones from the Hahenbanken area, offshore mid Norway. In: Spencer, A.M. et al. (eds): Habitat of hydrocarbons on the Norwegian continental shelf, 275-286. London: Graham \& Trotman Ltd.

Bojesen-Koefoed, J.A., Peter Nytoft, H.P., Petersen, H.I., Piasecki, S. \& Pilgaard, A. 2018: Petroleum potential of the Upper Jurassic Hareelv Formation, Jameson Land, East Greenland. In: Ineson, J. \& Bojesen-Koefoed, J.A. (eds): Petroleum geology of the Upper Jurassic - Lower Cretaceous of East and North-East Greenland: Blokelv-1 borehole, Jameson Land Basin. Geological Survey of Denmark and Greenland Bulletin 42, 85-113 (this volume). 
Boles, J.R. 1978: Active ankerite cementation in the subsurface Eocene of Southwest Texas. Contributions to Mineralogy and Petrology $68,13-22$.

Dutton, S.P. \& Loucks, R.G. 2010: Reprint of: Diagenetic controls on evolution of porosity and permeability in lower Tertiary Wilcox sandstones from shallow to ultradeep (200-6700 m) burial, Gulf of Mexico Basin, U.S.A. Marine and Petroleum Geology 27, 1775-1787.

Ehrenberg, S.N. 1989: Assessing the relative importance of compaction processes and cementation to reduction of porosity in sandstones: discussion; compaction and porosity evolution of Pliocene Sandstones, Ventura Basin, California: discussion. AAPG Bulletin 73, 1274-1276.

Esbensen, K. 2010: Multivariate data analysis - in practice. 5th edition, 598 pp. Oslo: CAMO Software.

Green, P.F. \& Japsen, P. 2018: Burial and exhumation history of the Jameson Land Basin, East Greenland, estimated from thermochronological data from the Blokelv-1 core. In: Ineson, J. \& BojesenKoefoed, J.A. (eds): Petroleum geology of the Upper Jurassic Lower Cretaceous of East and North-East Greenland: Blokelv-1 borehole, Jameson Land Basin. Geological Survey of Denmark and Greenland Bulletin 42, 133-147 (this volume).

Hansen, K., Bergman, S.C. \& Henk, B. 2001: The Jameson Land ba$\sin$ (east Greenland): a fission track study of the tectonic and thermal evolution in the Cenozoic North Atlantic spreading regime. Tectonophysics 331, 307-339.

Hillier, S. 2000: Accurate quantitative analysis of clay and other minerals in sandstones by XRD: comparison of a Rietveld and a reference intensity ratio (RIR) method and the importance of sample preparation. Clay Minerals 35, 291-302.

Houseknecht, D.W. 1987: Assessing the relative importance of compaction processes and cementation to reduction of porosity in sandstones. AAPG Bulletin 71, 633-642.

Jahren, J. \& Ramm, M. 2000: The porosity-preserving effects of microcrystalline quartz coatings in arenitic sandstones: examples from the Norwegian continental shelf. Special Publication of the International Association of Sedimentologists 29, 271-280.

Japsen, P., Green, P.F., Bonow, J.M., Nielsen, T.F.D. \& Chalmers, J.A. 2014: From volcanic plains to glaciated peaks: Burial, uplift and exhumation history of southern East Greenland after opening of the NE Atlantic. Global and Planetary Change 116, 91-114.

Larsen, H.C. \& Marcussen, C. 1992: Sill-intrusion, flood basalt emplacement and deep crustal structure of the Jamesom Land Basin, East Greenland. Geological Society of Special Publication (London) 68, 365-386.

Larsen L.M. 2018: Igneous intrusions in the cored Upper Jurassic succession of the Blokelv-1 core, Jameson Land Basin, East Greenland. In: Ineson, J \& Bojesen-Koefoed, J.A. (eds): Petroleum geology of the Upper Jurassic - Lower Cretaceous of East and North-East Greenland: Blokelv-1 borehole, Jameson Land Basin. Geological Survey of Denmark and Greenland Bulletin 42, 127-132 (this volume).

Larsen, L.M. \& Surlyk, F. 2003: Shelf-edge delta and slope deposition in the Upper Callovian - Middle Oxfordian Olympen Formation, East Greenland. In: Ineson, J. \& Surlyk, F. (eds): Geological Survey of Denmark and Greenland Bulletin 1, 931-948.

Lindgreen, H. \& Surlyk, F. 2000: Upper Permian-Lower Cretaceous clay mineralogy of East Greenland: provenance, palaeoclimate and volcanicity. Clay Minerals 35, 791-806.

Mathiesen, A., Bidstrup, T. \& Christiansen, F.G. 2000: Denudation and uplift history of the Jameson Land basin, East Greenland constrained from maturity and apatite fission track data. Global and Planetary Change 24, 275-301.

McCusker, L.B., Von Dreele, R.B., Cox, D.E., Louër, D. \& Scardi, P. 1999: Rietveld refinement guidelines. Journal of Applied Crystallography 32, 36-50.

Morad, S., Ketzer, J.M. \& De Ros, L.F. 2000: Spatial and temporal distribution of diagenetic alterations in siliciclastic rocks: implications for mass transfer in sedimentary basins. Sedimentology 47 (Suppl. 1), 95-120.

Moro, M.C., Cembranos, M.L. \& Fernandez, A. 2001: Celsian, $(\mathrm{Ba}, \mathrm{K})$-feldspar and cymrite from sedex barite deposits of Zamora, Spain. The Canadian Mineralogist 39, 1039-1051.

Olivarius, M., Weibel, R., Hjuler, M.L., Kristensen, L., Mathiesen, A., Nielsen, L.H. \& Kjøller, C. 2015: Diagenetic effects on porositypermeability relationships in red beds of the Lower Triassic Bunter Sandstone Formation in the North German Basin. Sedimentary Geology 321, 139-153.

Olivarius, M., Bjerager, M., Knudsen, C., Keulen, N., \& Kokfelt, T. 2018: Provenance of basinal sandstones in the Upper Jurassic Hareelv Formation, Jameson Land Basin, East Greenland. In: Ineson, J. \& Bojesen-Koefoed, J.A. (eds): Petroleum geology of the Upper Jurassic - Lower Cretaceous of East and North-East Greenland: Blokelv-1 borehole, Jameson Land Basin. Geological Survey of Denmark and Greenland Bulletin 42, 115-126 (this volume).

Ramm, M., Forsberg, A.W. \& Jahren, J.S. 1997: Porosity-depth trends in deeply buried Upper Jurassic reservoirs in the Norwegian Central Graben: An example of porosity preservation beneath the normal economic basement by grain-coating microquartz. In: Kupecz, J.A., Gluyas, J. \& Bloch, S. (eds): Reservoir quality prediction in sandstones and carbonates. American Association of Petroleum Geologists Memoir 69, 177-199.

Rietveld, H.M. 1969: A profile refinement method for nuclear and magnetic structures. Journal of Applied Crystallography 2, 65-71.

Slater, C. \& Cohen, L. 1962: A centrifugal particle size analyser. Journal of Scientific Instruments 39, 614-617.

Stemmerik, L., Christensen, F.G., Piasecki, S., Jordt, B., Marcussen, C. \& Nøhr-Hansen, H. 1992: Depositional history and petroleum geology of the Carboniferous to Cretaceous sediments in the northern part of East Greenland. Norwegian Petroleum Federation, Special Publication 2, 67-87.

Surlyk, F. 2003: The Jurassic of East Greenland: a sedimentary record of thermal subsidence, onset and culmination of rifting. In: Ineson, J.R., Surlyk, F. (eds): The Jurassic of Denmark and Greenland. Geological Survey of Denmark and Greenland Bulletin 1, 659-722.

Surlyk, F. \& Noe-Nygaard, N. 2005: A forced regressive shelf-margin wedge formed by transition-slope progradation: lowermost Cretaceous Rauk Plateau Member, Jameson Land, East Greenland. Bulletin of the Geological Society of Denmark 52, 227-243.

Surlyk, F., Gjelberg, J. \& Noe-Nygaard, N. 2007: The Upper Jurassic 
Hareelv Formation of East Greenland: A giant sedimentary injection complex. In: Hurst, A. \& Cartwright, J. (eds): Sand injectites: Implications for hydrocarbon exploration and production. AAPG Memoir 87, 141-149.
Therkelsen, J. 2016: Diagenesis and reservoir properties of Middle Jurassic sandstones, Traill Ø, East Greenland: The influence of magmatism and faulting. Marine and Petroleum Geology 78, 196-221.

Manuscript received 10 June 2016; revision accepted 29 August 2017 